\title{
The Influences of the Atlantic Multidecadal Oscillation on the Mean Strength of the North Pacific Subtropical High during Boreal Winter ${ }^{\mathscr{O}}$
}

\author{
KEWEI LyU, JiN-Yi Yu, AND HOUK PAEK \\ Department of Earth System Science, University of California, Irvine, Irvine, California
}

(Manuscript received 14 July 2016, in final form 22 September 2016)

\begin{abstract}
The Atlantic multidecadal oscillation (AMO) has been shown to be capable of exerting significant influences on the Pacific climate. In this study, the authors analyze reanalysis datasets and conduct forced and coupled experiments with an atmospheric general circulation model (AGCM) to explain why the winter North Pacific subtropical high strengthens and expands northwestward during the positive phase of the AMO. The results show that the tropical Atlantic warming associated with the positive AMO phase leads to a westward displacement of the Pacific Walker circulation and a cooling of the tropical Pacific Ocean, thereby inducing anomalous descending motion over the central tropical Pacific. The descending motion then excites a stationary Rossby wave pattern that extends northward to produce a nearly barotropic anticyclone over the North Pacific. A diagnosis based on the quasigeostrophic vertical velocity equation reveals that the stationary wave pattern also results in enhanced subsidence over the northeastern Pacific via the anomalous advections of vorticity and temperature. The anomalous barotropic anticyclone and the enhanced subsidence are the two mechanisms that increase the sea level pressure over the North Pacific. The latter mechanism occurs to the southeast of the former one and thus is more influential in the subtropical high region. Both mechanisms can be produced in forced and coupled AGCMs but are displaced northward as a result of stationary wave patterns that differ from those observed. This explains why the model-simulated North Pacific sea level pressure responses to the AMO tend to be biased northward.
\end{abstract}

\section{Introduction}

The Atlantic multidecadal oscillation (AMO) is a dominant mode of decadal climate variability and is characterized by basin-scale ocean surface warming or cooling in the North Atlantic (NA). One important driver of the AMO is the slowly varying Atlantic meridional overturning circulation (AMOC) (e.g., Delworth et al. 1993); their relationship is such that the NA is warmer when the AMOC strengthens. Recent studies have argued that stochastic atmospheric forcing in the midlatitudes and thermal coupling in the tropics play a key role (e.g., Clement et al. 2015). Despite its

Supplemental information related to this paper is available at the Journals Online website: http://dx.doi.org/10.1175/ JCLI-D-16-0525.s1.

Corresponding author address: Dr. Kewei Lyu, Department of Earth System Science, University of California, Irvine, 2101C Croul Hall, Irvine, CA 92697-3100.

E-mail: lyuk1@uci.edu controversial origin, it has been widely reported that the AMO affects the weather and climate not only in and around the Atlantic (Knight et al. 2006) but also across the globe: for example, the Indian summer monsoon (Goswami et al. 2006), Siberian precipitation (Sun et al. 2015), and Antarctic sea ice ( $\mathrm{Li}$ et al. 2014).

The transbasin influence of the Atlantic Ocean on Pacific climate and variability has been receiving much attention. During the past two decades, the tropical Pacific has experienced remarkable changes in its mean state with a cooling tropical eastern Pacific and intensified surface easterly winds along the equator, which have also been linked to the slowdown in global surface warming in the recent decade (England et al. 2014). Recent studies have suggested that these changes can be partly attributed to concurrent tropical Atlantic warming (McGregor et al. 2014; Li et al. 2015), a combined effect of the positive AMO phase and anthropogenic forcing. The tropical Atlantic warming also contributes to the changes in the Southern Hemisphere climate (Simpkins et al. 2014). Similarly, Kucharski et al. (2016) found that the warm phase of the AMO leads to cooling 


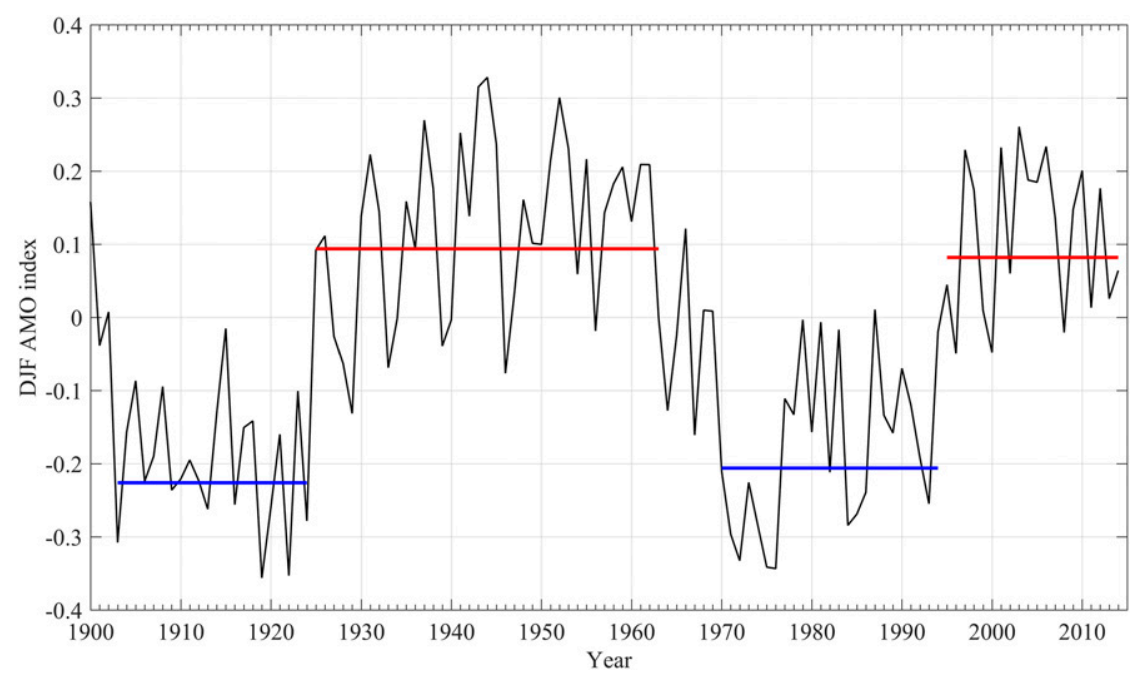

FIG. 1. Winter (DJF) AMO index $\left({ }^{\circ} \mathrm{C}\right)$ defined as the detrended, area-weighted average of SST anomalies in the North Atlantic. The AMO positive (negative) periods are marked by the red (blue) lines.

in the central-eastern tropical Pacific and surface easterly wind anomalies in the central tropical Pacific. In fully coupled ocean-atmosphere model experiments, a weakening of the AMOC (i.e., the cold phase of the AMO) usually leads to warming in the southeastern tropical Pacific, a southward shift of the intertropical convergence zone (ITCZ) over both the Atlantic and Pacific, extratropical North Pacific (NP) cooling, and a deepening of the winter Aleutian low (Zhang and Delworth 2005; Timmermann et al. 2007; Wu et al. 2008; Okumura et al. 2009). Therefore, Zhang and Delworth (2007) suggested that the AMO is an important source of NP multidecadal variability.

The AMO has also been suggested to modulate the El Niño-Southern Oscillation (ENSO) variability with evidence from observations and coupled model experiments (Dong et al. 2006; Dong and Sutton 2007; Timmermann et al. 2005; 2007; Kang et al. 2014; Svendsen et al. 2014; Sung et al. 2015). There exists some consensus among these studies that the cold phase of the $\mathrm{AMO}$ and/or the weakening of the AMOC tend to intensify ENSO variability, although different mechanisms are involved. However, these studies did not distinguish the different types of ENSO events and their distinct origins. Besides the conventional ENSO events that develop along the western coast of South America and extend westward, it is becoming increasingly evident that there is another type of ENSO event with the maximum sea surface temperature (SST) anomalies in the central tropical Pacific, referred to as the central Pacific ENSO (Yu and Kao 2007; Kao and Yu 2009), dateline El Niño (Larkin and Harrison 2005), El Niño
Modoki (Ashok et al. 2007), or warm pool El Niño (Kug et al. 2009). This type of ENSO variability is more related to forcing from the extratropical NP, with SST anomalies initially appearing in the northeastern subtropical Pacific and then spreading into the central tropical Pacific (Yu et al. 2010; Yu and Kim 2011). This type of El Niño event has become more frequent in recent decades (Ashok et al. 2007; Kug et al. 2009; Lee and McPhaden 2010). Since the early 1990s, the primary location of ENSO events shifted from the eastern tropical Pacific to the central tropical Pacific, while the influence of the extratropical NP forcing on the tropical Pacific has become stronger and more effective ( $\mathrm{Yu}$ et al. 2012a; Yeh et al. 2015). The relationship between the tropical Pacific ENSO variability and the Southern Hemisphere climate also changed around the same time (Yu et al. 2015b). Recently, Yu et al. (2015a) linked the increased occurrences of the central Pacific El Niño events to the change in AMO phase. They proposed that, when the AMO switched from its negative phase to its positive phase in the early 1990s (Fig. 1), the NP subtropical high intensified, leading to stronger trade winds and thus enhanced subtropical air-sea coupling. This enhanced coupling allows subtropical SST anomalies to extend more easily into the central tropical Pacific.

In this study we identify the physical mechanisms by which the positive phase of the AMO can intensify the NP subtropical high. Besides the atmospheric reanalysis products, an atmospheric general circulation model (AGCM) experiment and another coupled atmosphereocean model experiment were conducted to validate the 
influence of the AMO on the NP subtropical high and also verify the relevant climate processes linking them together. Our analyses are focused on boreal winter when the AMO has its strongest expressions on the NP sea level pressure (SLP) patterns including the subtropical high region (e.g., Sutton and Hodson 2007).

\section{Data and model experiments}

Two atmospheric reanalysis datasets, the National Centers for Environmental Prediction (NCEP)National Center for Atmospheric Research (NCAR) reanalysis for the period 1948-2015 (Kalnay et al. 1996) and the Twentieth Century Reanalysis (20CR; Compo et al. 2011) covering the period 1851-2014, are mainly used in this study. We also analyzed the European Centre for Medium-Range Weather Forecasts (ECMWF) twentieth century reanalysis (ERA-20C; Stickler et al. 2014) over 1900-2010 and obtained similar results (shown in Figs. S1e-S6e of the supplementary material). The SST data used (for the period 1854-2015) are from the National Oceanic and Atmospheric Administration (NOAA) Extended Reconstructed Sea Surface Temperature (ERSST; Smith et al. 2008) product. The monthly data were averaged from December through the following February (DJF) to represent the boreal winter climate. The data at each grid point were linearly detrended to remove the long-term climate change signal.

Following Enfield et al. (2001), the AMO index (Fig. 1) is defined as the detrended, area-weighted average of SST anomalies in the North Atlantic. In this study, the AMO-related anomalies were calculated as the difference between the mean of two positive AMO periods (1925-63 and 1995-2014) and the mean of two negative AMO periods (1903-24 and 1970-94). For the shorter NCEP-NCAR reanalysis dataset, only the last two periods (1970-94 and 1995-2014) were used to calculate the difference. Similar composite differences can be derived (not shown) when using slightly different AMO periods as in previous studies (Kang et al. 2014; Sung et al. 2015). The composite results do not change when the PDO-related signals are removed from the data using a linear regression (see Figs. S1a-S6a of the supplementary material). The regression patterns onto the 11-yr smoothed AMO index (see Figs. S1b-S6b of the supplementary material) share similar features as the composite difference patterns. The difference patterns for the two AMO phase change events are fairly consistent with each other (see Figs. S1c-S6c and S1dS6d in the supplementary material).

Numerical model experiments were performed using the NCAR Community Atmospheric Model, version
3.0, (CAM3.0; Collins et al. 2006) with a T42 Eulerian spectral resolution $(128 \times 64$ grid points $)$ and 26 vertical levels. Two sets of model experiments were carried out with the prescribed AMO SSTs in the NA $\left(0^{\circ}-70^{\circ} \mathrm{N}\right)$ but different configurations outside the NA. The first set of the experiments is forced AGCM experiments, where climatological SSTs are prescribed in other ocean basins. In the second set of the experiments, the AGCM is coupled to a mixed layer slab ocean model (SOM) in other ocean basins, which is referred to as the AGCM-SOM experiments. Compared to the AGCM experiments that only allow teleconnections through the atmosphere, the AGCM-SOM experiments predict the SSTs outside the NA and also take into account the local air-sea coupling.

Each set of the model experiments includes an AMO positive-phase run and an AMO negative-phase run, in which the AMO SST forcing were added to or subtracted from the climatological SST in the NA, respectively. The AMO SST forcing used was 4 times the regressed SST anomalies onto the AMO index. The scaling factor of 4 was used to make sure that the model produces steady and strong enough responses to the AMO SST forcing with short integrations (Sutton and Hodson 2007; Yu et al. 2015a). The AGCM (AGCMSOM) was integrated for 46 (120) years for each run, and model output of the last 40 (100) years were used for our analysis. Using only the last 40 years of the AGCMSOM output gives very similar results. The simulated AMO responses were defined as the mean state differences between the AMO positive- and negative-phase runs. Following Sutton and Hodson (2007), the differences were scaled by a factor of $1 / 4$ for direct comparison with the observational results.

\section{Results}

\section{a. Large-scale climate responses to the $A M O$}

The NA SST anomaly pattern associated with the positive phase of the AMO has a horseshoe-like shape, with warming centers in the tropical NA south of $20^{\circ} \mathrm{N}$ and the extratropical NA separated by a less-warming band in between (Fig. 2). Note that the NA SST anomalies derived from the composite differences (Fig. 2a) and the regression analysis (Fig. 2b) show very similar distributions. The AMO positive phase is also associated with warming in the extratropical NP and cooling in the central tropical Pacific (Fig. 2a). The AGCM-SOM experiment broadly replicates the observed SST response patterns in the Pacific to the AMO forcing [i.e., the opposite signs of SST anomalies in the NP and tropical Pacific (Fig. 2b)]. 


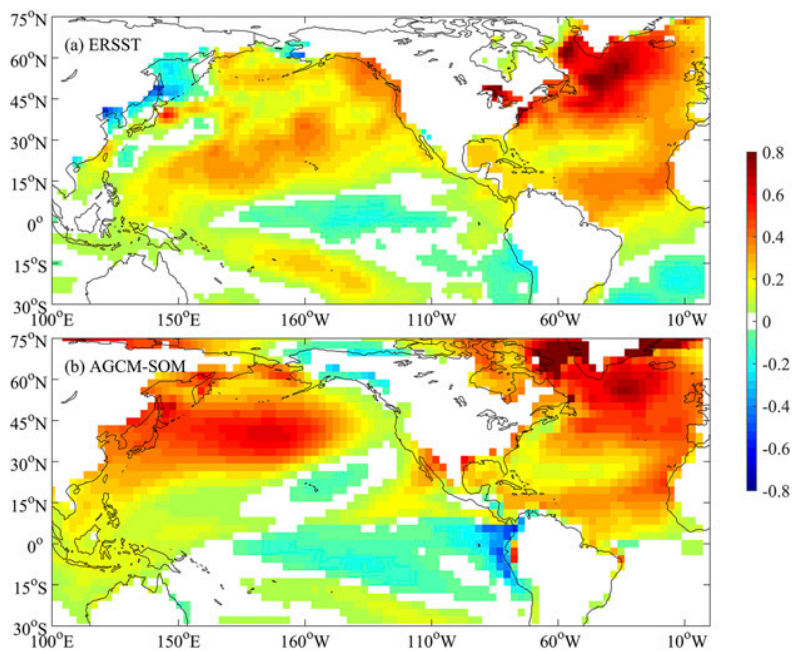

FIG. 2. The AMO-related winter SST anomalies $\left({ }^{\circ} \mathrm{C}\right)$ from (a) the ERSST dataset and (b) the AGCM-SOM experiment, calculated as differences between the AMO positive and negative periods for observations or between the AMO positive and negative runs for the model experiment. Note that in (b) the North Atlantic SST anomalies were prescribed based on the regressions onto the AMO index.

The AMO induces winter SLP responses both locally over the NA and remotely over the NP (Fig. 3). Two reanalysis datasets show that, during the AMO positive phase, both the subpolar low and the subtropical high over the NA weaken with positive SLP anomalies north of about $50^{\circ} \mathrm{N}$ and negative anomalies to the south
(Figs. 3a,b). This anomalous SLP pattern resembles the negative phase of the North Atlantic Oscillation (NAO), the dominant mode of winter atmospheric variability in the NA, suggesting possible connections between the AMO and multidecadal fluctuations in the NAO (Peings and Magnusdottir 2014, 2015). However, both the forced AGCM and coupled AGCM-SOM experiments produce negative SLP anomalies over the whole NA (Figs. 3c,d), likely a direct response to the local positive SST anomalies. Compared with the reanalysis datasets, the model-simulated NA SLP responses are much weaker. This model deficiency may be due to the lack of NA atmosphere-ocean interaction in the prescribed model experiments, but the actual reasons are still unclear. Peings et al. (2016) noticed that global coupled climate models also do not agree on the sign of the high-latitude NA winter SLP response to the AMO.

The winter SLP climatology over the NP comprises the Aleutian low to the north and the subtropical high over the eastern subtropics (Fig. 3). When the AMO is in its positive phase, positive SLP anomalies occur mainly over the eastern part of the NP with a northwestsoutheast orientation in the 20CR and NCEP-NCAR reanalysis (Figs. 3a,b). The region of increased SLP covers the full extent of the subtropical high with a center of action between the Aleutian low and the subtropical high. Therefore, both reanalysis datasets agree that the NP winter subtropical high intensifies and expands northwestward during the positive phase of the (a) $20 \mathrm{CR}$

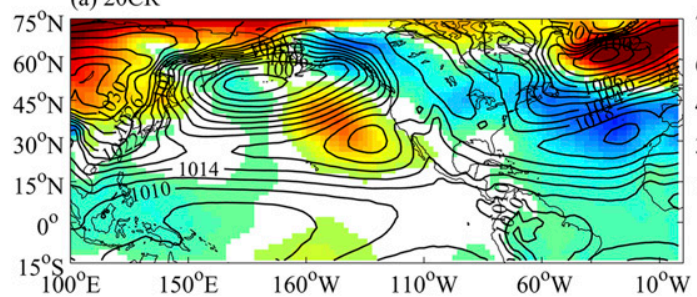

(c) Forced AGCM

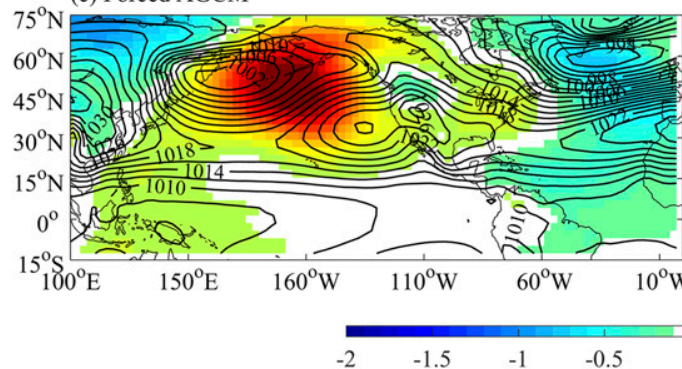

(b) NCEP-NCAR

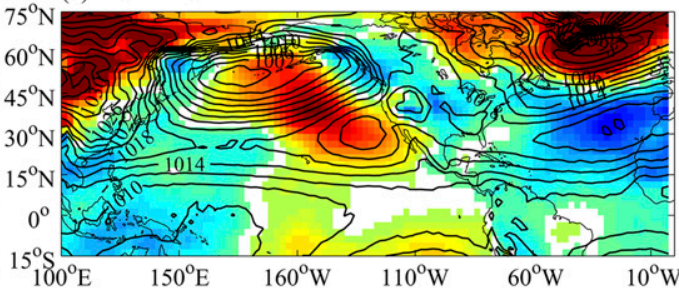

(d) AGCM-SOM

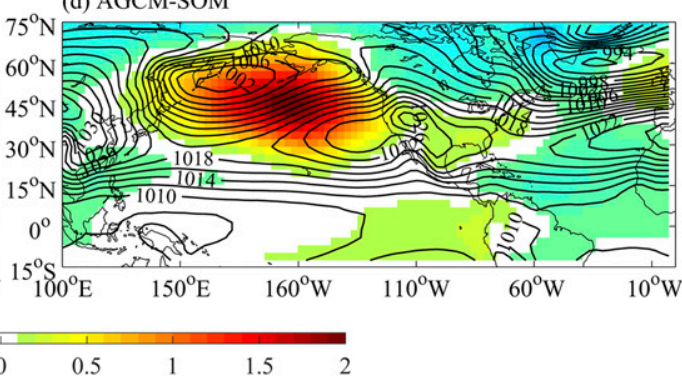

FIG. 3. The winter SLP climatology (hPa; contours) and AMO-related winter SLP anomalies (hPa; shading) from (a) 20CR, (b) the NCEP-NCAR reanalysis, (c) the forced AGCM experiment, and (d) the AGCM-SOM experiment, calculated as differences between AMO positive and negative periods for the reanalysis datasets or between AMO positive and negative runs for the model experiments. 

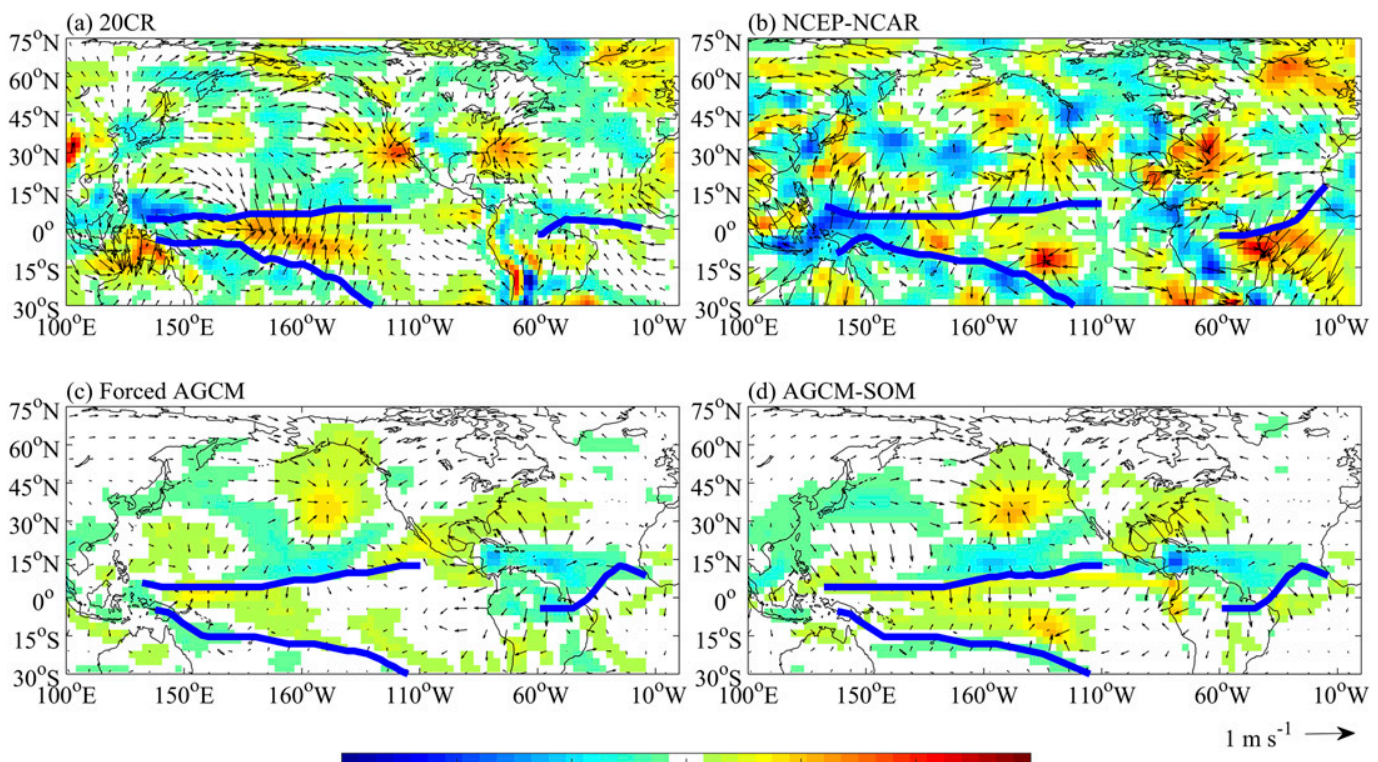

$-0.03$

$-0.02$

$-0.01$

0

0.01

0.02

0.03

FIG. 4. As in Fig. 3, but for the AMO-related winter vertical velocity anomalies ( $\mathrm{Pa} \mathrm{s}^{-1}$; shading, positive means downward) at $450 \mathrm{hPa}$ and divergent wind anomalies ( $\mathrm{m} \mathrm{s}^{-1}$; vectors) at $200 \mathrm{hPa}$. The ITCZ and SPCZ are marked by blue lines as the climatological upward velocity maxima.

AMO. Since the positive SLP anomalies extend northwestward to weaken the Aleutian low in NCEP-NCAR reanalysis (Fig. 3b) but not in 20CR (Fig. 3a), the influence of the AMO on the mean strength of the Aleutian low is still uncertain. In the model experiments, the positive SLP anomalies cover nearly the entire NP but with the maximum anomalies still located around the boundary of the Aleutian low and the subtropical high (Figs. 3c,d). Compared with the reanalysis datasets, it seems that the model-produced NP winter SLP responses tend to be biased northwestward with less emphasis on the subtropical high region.

We first examine the AMO-related vertical motion changes in the atmosphere using the vertical velocity at $450 \mathrm{hPa}$ and the divergent wind at $200 \mathrm{hPa}$ (Fig. 4). With the imposed basin-scale NA warming, the model experiments show a clear response over the tropical Atlantic but a much weaker extratropical response compared with the reanalysis datasets. Over the tropical Atlantic, the model experiments reproduce the anomalous ascending motions over northern South America and the tropical NA, the associated upper-level divergent flow, and the surrounding anomalous descending motions. The ascending (descending) motion anomalies to the north (south) of the climatological ascending motion maxima suggest a northward shift of the Atlantic ITCZ, which is a robust AMO-induced feature that has been found in previous studies (e.g., Hodson et al. 2010). The precipitation response shows a similar north-south dipolar structure over the tropical Atlantic (not shown).

The change in AMO phase is also accompanied by remarkable changes in the vertical motion over the tropical Pacific (Fig. 4). Both reanalysis datasets and the model experiments show anomalous descending motions over the central tropical Pacific (roughly between $150^{\circ} \mathrm{E}$ and $110^{\circ} \mathrm{W}$ ) during the positive phase of the AMO, consistent with Kucharski et al. (2016). There are also ascending motion anomalies to the north and south of the descending motion anomalies over the central tropical Pacific, indicating a northward shift of the $\mathrm{Pa}$ cific ITCZ and a southward shift of the South Pacific convergence zone (SPCZ), respectively. Compared with the forced AGCM experiment (Fig. 4c), the AGCMSOM experiment generates a stronger response in the vertical motion field over the tropical Pacific (Fig. 4d). This difference highlights the role of tropical Pacific airsea coupling in reinforcing the remote responses of the tropical Pacific to the tropical Atlantic, also noticed by McGregor et al. (2014). Both sets of model experiments fail to reproduce the strong ascending motion anomalies over the western tropical Pacific seen in the reanalysis datasets. One possible reason could be that the local SST forcing in the western tropical Pacific is either absent in the forced AGCM experiment or weaker than the observations in the AGCM-SOM experiment (Fig. 2). A fully coupled climate model including full ocean dynamics may perform better in simulating the SST and 
precipitation responses in the western tropical Pacific to the Atlantic forcing (Zhang and Delworth 2005).

Of particular interest is another region of anomalous descending motion and upper-level convergence over the northeastern Pacific during the positive phase of the AMO (Fig. 4). Since the NP subtropical high is also located over the northeastern Pacific and is characterized by subsiding air, the anomalous descending motion could intensify the NP subtropical high. This region of descending motion anomalies is centered at around $30^{\circ} \mathrm{N}, 120^{\circ} \mathrm{W}$ off the southwestern coast of North America and covers the latitude band between $15^{\circ}$ and $45^{\circ} \mathrm{N}$ in $20 \mathrm{CR}$ (Fig. 4a), while it appears with a clearer northwest-southeast orientation over a larger domain between $15^{\circ}$ and $60^{\circ} \mathrm{N}$ in the NCEP-NCAR reanalysis (Fig. 4b). Compared with the reanalysis datasets, the model-produced descending motion anomalies are located more northwestward between $20^{\circ}$ and $60^{\circ} \mathrm{N}$ and between $170^{\circ}$ and $120^{\circ} \mathrm{W}$, with the center at around $32^{\circ} \mathrm{N}, 150^{\circ} \mathrm{W}$ (Figs. $4 \mathrm{c}, \mathrm{d}$ ). To some extent, the descending motion anomalies may be directly related to the tropical Pacific forcing via the local Hadley-type circulation, with ascending motion anomalies to the south and upper-level northerly wind anomalies toward the center. However, this mechanism does not explain the convergent wind anomalies from other directions that also contribute to the descending motions. In the next section we will present the results of a detailed investigation into the causes of the anomalous descending motions over the northeastern Pacific.

One potential way to link the tropical Atlantic forcing to the tropical Pacific is through the adjustment of the Walker circulation along the equator (McGregor et al. 2014; Kucharski et al. 2016). Here we use the zonal mass streamfunction $\Psi$ to describe the Walker circulation (e.g., Yu and Boer 2002), defined as follows:

$$
\Psi=\frac{2 \pi a}{g} \int_{0}^{p} \overline{u_{d}} d p
$$

where $g$ is the gravitational acceleration $\left(9.8 \mathrm{~m} \mathrm{~s}^{-2}\right), a$ is the radius of Earth, $p$ is the pressure, and $\overline{u_{d}}$ is the zonal component of the divergent wind averaged between $5^{\circ} \mathrm{S}$ and $5^{\circ} \mathrm{N}$. The vertical integration was performed from the top level downward to the surface level and assumes $\Psi=0$ at the top of the atmosphere. Positive values of $\Psi$ represent clockwise circulations and negative values anticlockwise circulations. The zero lines of $\Psi$ can be viewed as the boundaries of the Walker circulation. The maximum value of $\Psi$ is used as a measure of the intensity of the Walker circulation.

The climatological Pacific Walker circulation is a clockwise circulation cell spanning the equatorial
Pacific, with its primary rising branch over the western equatorial Pacific and its primary sinking branch over the eastern equatorial Pacific (Fig. 5). During the positive phase of the AMO, the ascending motion anomalies over the tropical Atlantic force an anomalous anticlockwise circulation, indicated by the negative $\Psi$ anomalies east of $150^{\circ} \mathrm{W}$ in $20 \mathrm{CR}$ or east of $130^{\circ} \mathrm{W}$ in other datasets. The eastern boundary of the Pacific Walker cell extends westward because of the negative $\Psi$ anomalies around it. To the west, there are positive $\Psi$ anomalies (i.e., an anomalous clockwise circulation) on the western side of the Pacific Walker cell, indicating a westward displacement of its western boundary. Both the anomalous clockwise circulation on the western side of the Pacific Walker cell and the anomalous anticlockwise circulation on the eastern side have their sinking branches over the central tropical Pacific. Therefore, the Pacific Walker cell as a whole is displaced westward during the positive phase of the AMO, resulting in anomalous descending motion over the central tropical Pacific (Fig. 4).

The two reanalysis datasets and two model experiments show the opposite signs of $\Psi$ anomalies on both sides of the Pacific Walker cell during the positive phase of the AMO, but with some differences in the details (Fig. 5). The detailed differences between the observed and simulated Walker circulation changes determine the different magnitudes and longitude locations of the central tropical Pacific descending motion anomalies (Fig. 4). The negative $\Psi$ anomalies on the eastern side extend through all pressure levels for 20CR and the model experiments but are only found below approximately $400 \mathrm{hPa}$ in the NCEP-NCAR reanalysis (Fig. 5b). In addition, the NCEP-NCAR reanalysis shows much larger positive $\Psi$ anomalies (i.e., clockwise) on the western side of the Pacific Walker cell and also negative $\Psi$ anomalies (i.e., anticlockwise) farther west of $130^{\circ} \mathrm{E}$ (Fig. $5 \mathrm{~b}$ ), corresponding to the stronger ascending motion anomalies over the Maritime Continent around $130^{\circ} \mathrm{E}$ (Fig. 4b). The inconsistencies between the NCEP-NCAR reanalysis and the other datasets could be due to its short length. The forced AGCM experiment produces positive $\Psi$ anomalies mainly around the western boundary of the Pacific Walker cell (Fig. 5c). Accordingly, the maximum anomalies in the descending motions appear at around $150^{\circ} \mathrm{E}$ (Fig. 4c). In contrast, the AGCM-SOM experiment, which allows the local air-sea coupling over the tropical Pacific, produces patterns of $\Psi$ anomalies (Fig. 5d) and thus the descending motion anomalies over the tropical Pacific (Fig. 4d) that more closely resemble those of the reanalysis datasets. In 20CR, the overlap of negative $\Psi$ anomalies with the climatological location of the $\Psi$ 

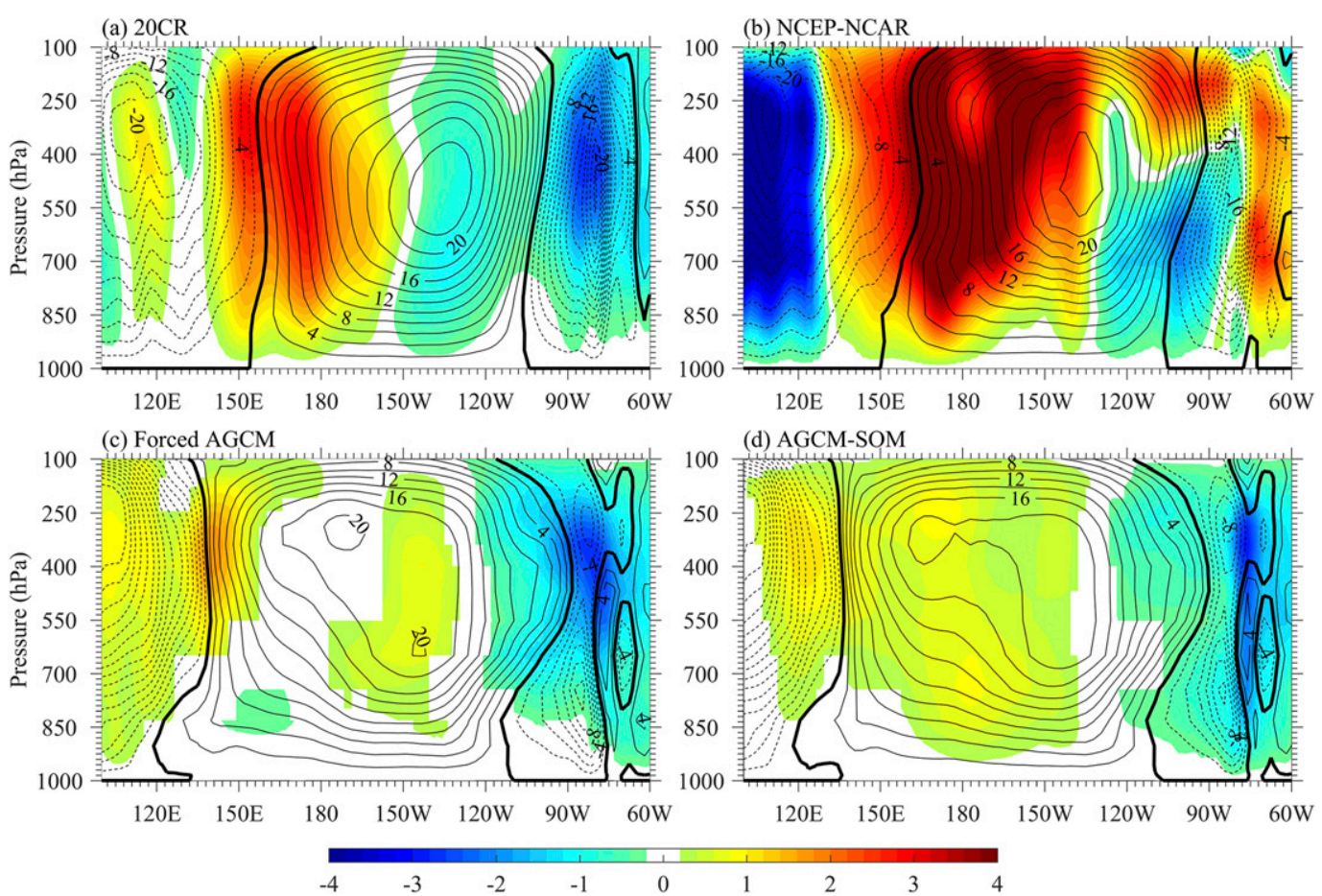

FIG. 5. The climatological winter zonal mass streamfunction $\left(10^{10} \mathrm{~kg} \mathrm{~s}^{-1}\right)$ along the equator (contours) and the AMO-related winter anomalies (shading) from (a) 20CR, (b) the NCEP-NCAR reanalysis, (c) the forced AGCM experiment, and (d) the AGCM-SOM experiment. Positive denotes clockwise circulation. The zero contours are thickened, and negative contours are dashed.

maxima at around $135^{\circ} \mathrm{W}$ suggests a weakening of the Pacific Walker circulation (Fig. 5a). On the contrary, the NCEP-NCAR reanalysis and model experiments have positive $\Psi$ anomalies within the climatological center (i.e., a strengthening of the Pacific Walker circulation) (Figs. 5b-d). Therefore, the impact of the AMO on the intensity of the Pacific Walker circulation is still uncertain. Recently, Ma and Zhou (2016) showed that the Pacific Walker circulation has strengthened and shifted westward during the period 1979-2012. Since there is an upward trend in the AMO index over this period (Fig. 1), we suggest that the phase transition of the AMO at least plays a role in the observed westward displacement of the Pacific Walker circulation.

The anomalous vertical motions over the tropics could also induce changes in tropical convection activity. Over the tropical Atlantic, the ascending motions during the positive phase of the AMO correspond to the negative OLR anomalies, indicating enhanced deep convection and also enhanced convective heating of the atmosphere (Fig. 6). In contrast, the descending motions over the central tropical Pacific lead to the positive OLR anomalies as deep convection is suppressed and thus negative anomalies in convective heating (Fig. 6). Tropical convective heating anomalies can directly excite a baroclinic response within the tropics (Gill 1980). This baroclinic vertical structure can be represented using the baroclinic streamfunction, calculated as $\psi_{c}=$ $\left(\psi_{850 \mathrm{hPa}}-\psi_{200 \mathrm{hPa}}\right) / 2$. Corresponding to the heating anomalies discussed above, there is a pair of baroclinic cyclones straddling the equator in the Atlantic and another pair of baroclinic anticyclones north and south of the equator in the Pacific, respectively (Fig. 6). These baroclinic responses are almost symmetric about the equator even if the heating anomalies are somewhat off the equator, consistent with the simple solutions of Heckley and Gill (1984) and other model results (Wang et al. 2010; Ji et al. 2014). The baroclinic circulation anomalies in the tropical Pacific in turn provide evidence that the descending motions over the central tropical Pacific are not only passive responses to the tropical Atlantic warming but also play an active role in modifying the local atmospheric circulation in the Pacific.

The remote response of the extratropical atmospheric circulation to tropical heating anomalies is dominated by barotropic signals (e.g., Hoskins and Karoly 1981; Webster 1981). The barotropic streamfunction, expressed as $\psi_{t}=\left(\psi_{850 \mathrm{hPa}}+\psi_{200 \mathrm{hPa}}\right) / 2$, exhibits anomalous stationary Rossby wave patterns with alternating centers of cyclones and anticyclones (Fig. 7). The barotropic 
(a) $20 \mathrm{CR}$

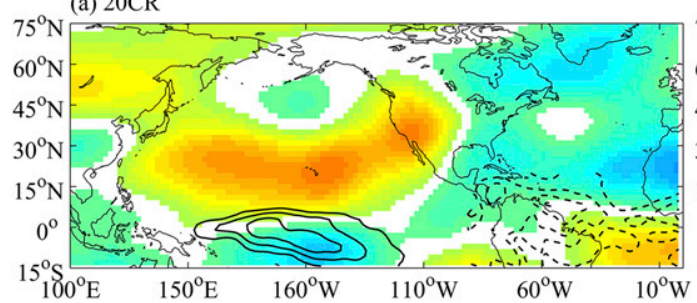

(c) Forced AGCM

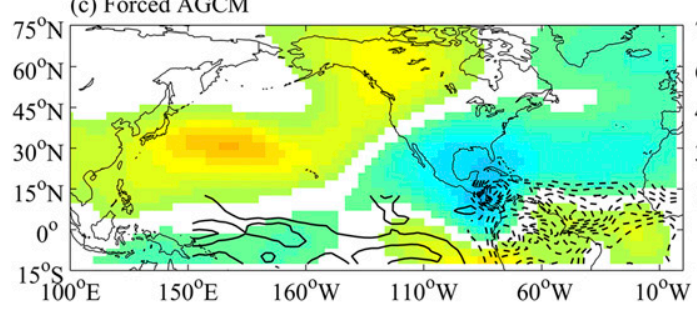

(b) NCEP-NCAR

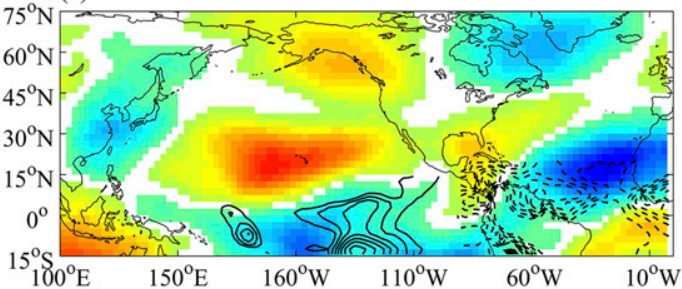

(d) AGCM-SOM

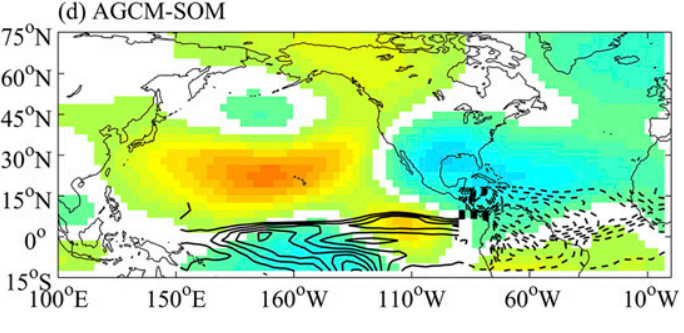

\begin{tabular}{lllllll}
\hline-3 & -2 & -1 & 0 & 1 & 2 & 3
\end{tabular}

FIG. 6. As in Fig. 3, but for the AMO-related winter baroclinic streamfunction anomalies $\left(10^{6} \mathrm{~m}^{2} \mathrm{~s}^{-1}\right.$; shading) with global zonal mean removed and OLR anomalies (contours with an interval of $2 \mathrm{~W} \mathrm{~m}^{-2}$ ). Negative contours are dashed and the zero contour is omitted.

wave responses in the reanalysis datasets and model experiments share similar large-scale features despite their distinct patterns. Over the NP, the stationary wave pattern seems to generally originate from the tropical Pacific, extend northward into the extratropical NP, and then turn eastward into North America. Such a stationary wave pattern is nearly a mirror image of that forced by El Niño-like tropical Pacific warm SST anomalies (e.g., Horel and Wallace 1981). The corresponding stationary wave activity flux (Plumb 1985) shows a poleward and eastward propagation of stationary wave activity into the subtropical NP and toward North America.

Associated with the descending motion and cooling source over the central tropical Pacific (see Fig. 6), a barotropic cyclone forms just north of the tropical forcing in the subtropical NP (south of $30^{\circ} \mathrm{N}$; Fig. 7). This barotropic cyclone strengthens the upper-level anomalies of the baroclinic response but weakens or even reverses the baroclinic response at lower levels (see Fig. 6). Such a relationship between the baroclinic and barotropic responses to tropical forcing is consistent
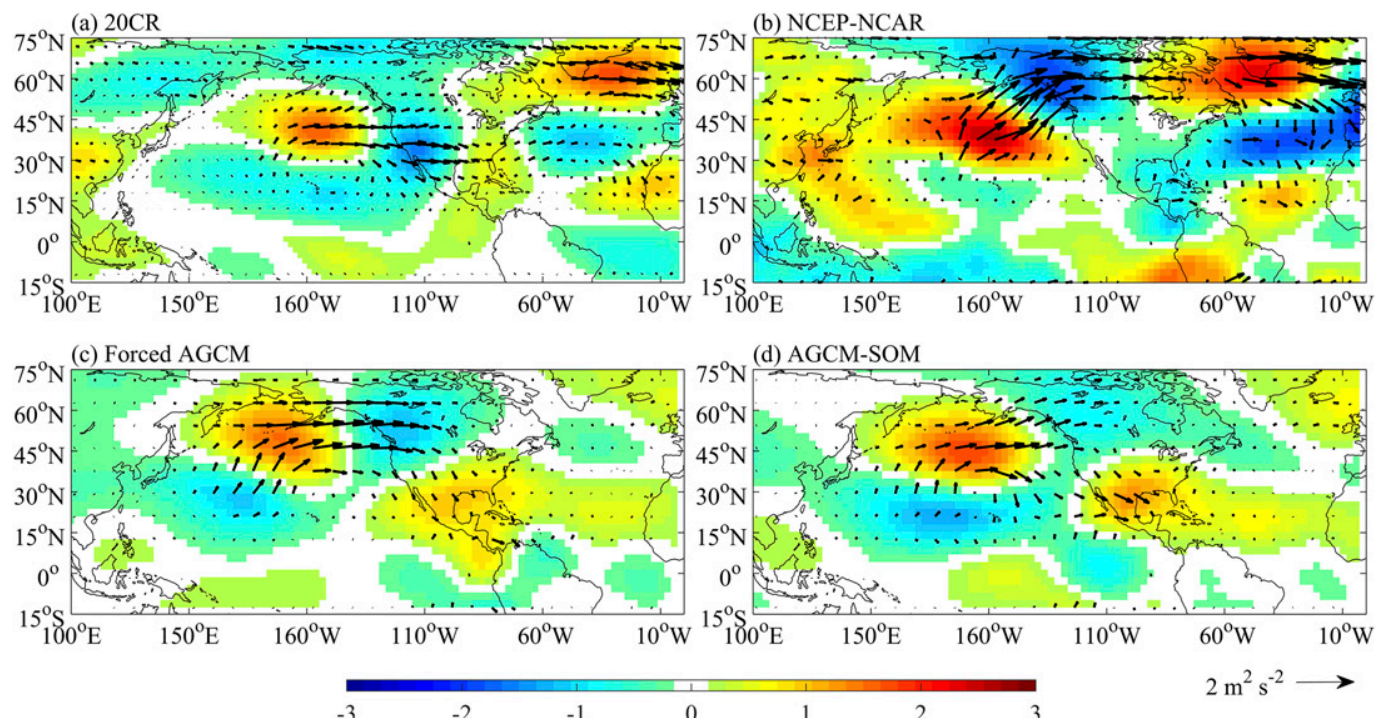

FIG. 7. As in Fig. 3, but for the AMO-related winter barotropic streamfunction anomalies $\left(10^{6} \mathrm{~m}^{2} \mathrm{~s}^{-1}\right.$; shading) with global zonal mean removed and the corresponding stationary wave activity flux $\left(\mathrm{m}^{2} \mathrm{~s}^{-2}\right.$; vectors). 
with that identified in a simple atmospheric model by Lee et al. (2009). Farther to the north there is an anomalous barotropic anticyclone over the NP (between $30^{\circ}$ and $60^{\circ} \mathrm{N}$; Fig. 7), where the anomalies associated with the baroclinic response are weak (Fig. 6). This equivalent barotropic anticyclone occupies part of the region where positive NP SLP anomalies were observed during the positive phase of the AMO (Fig. 3). Similarly, Okumura et al. (2009) found that an anomalous barotropic cyclone decreases SLPs over the NP in response to a weakening of the AMOC (i.e., the cold phase of the AMO). Lee et al. (2013) also reported that the suppressed convection in the tropics can force stationary barotropic Rossby waves and induce SLP anomalies in extratropical regions.

In the NA, there is also a wavelike structure with an anticyclone in the tropics, a cyclone in midlatitudes, and another anticyclone at high latitudes (Fig. 7). This structure appears to be the barotropic response to the heating source over the tropical Atlantic during the positive phase of the AMO. However, the corresponding wave activity flux does not show poleward propagation into the NA. Instead, in the reanalysis datasets, the NP wave train seems to extend into the NA, with eastward propagation of wave activity into the extratropical NA and southward propagation toward the tropical Atlantic (Figs. 7a,b). However, in the model experiments, there is no apparent propagation of wave activity into the NA. Instead, the NP wave train returns back to the tropics before reaching the Atlantic basin (Fig. 7c and d). Ding et al. (2014) also found that a stationary wave train originating from the tropical Pacific can extend into the NA to produce an NAO-like pattern. The lack of wave activity propagation from the NP into the NA may partly explain why the model experiments cannot produce the winter NAO-like response to the AMO forcing (Fig. 3).

Our results strongly suggest an active role for the tropical Pacific forcing in determining the extratropical NP responses although the AMO-related tropical forcing is in the tropical Atlantic. Based on fully coupled climate model experiments, Zhang and Zhao (2015) also found that extratropical NP responses to the tropical Atlantic SST forcing are mainly through such a tropical Pacific pathway. Simpkins et al. (2016) also noticed that the tropical Atlantic SST forcing can first influence the tropical Pacific through the Walker circulation and then result in a Rossby wave train emanating from the tropical Pacific into the Southern Hemisphere during austral winter.

The results presented in this section suggest that the barotropic wave response to anomalous descending motions over the central tropical Pacific is one main mechanism for the associated increase in the SLP over the NP during boreal winter and intensification of the NP subtropical high during the positive phase of the AMO. This wave response is also likely responsible for setting up the winter SLP responses over the NA region once the wave activity has propagated into the Atlantic sector.

\section{b. Diagnosis of the enhanced subsidence over the northeastern Pacific}

In this section, we use the $\omega$ (vertical velocity) equation to investigate the physical mechanisms that produce the enhanced subsidence over the northeastern Pacific (see Fig. 4) during the positive phase of the AMO. We have suggested that this enhanced subsidence is another reason, in addition to the barotropic wave response, for the intensification of the NP subtropical high during the positive phase of the AMO. The quasigeostrophic $\omega$ equation can be written as follows (e.g., Räisänen 1995):

$$
\begin{aligned}
\left(\sigma \nabla^{2}+f^{2} \frac{\partial^{2}}{\partial p^{2}}\right) \omega= & -f \frac{\partial}{\partial p}\left[-\mathbf{V}_{g} \cdot \nabla\left(\xi_{g}+f\right)\right] \\
& -\frac{R}{p} \nabla^{2}\left(-\mathbf{V}_{g} \cdot \nabla T\right)
\end{aligned}
$$

where $\sigma$ is the static stability, $f$ is the Coriolis parameter, $R$ is the gas constant for dry air $\left(287 \mathrm{~J} \mathrm{~kg}^{-1} \mathrm{~K}^{-1}\right), p$ is the pressure, $T$ is the air temperature, $\mathbf{V}_{g}$ is the geostrophic wind vector, and $\xi_{g}$ is the geostrophic vorticity. The lefthand side of (2) is similar to a three-dimensional Laplacian of the vertical velocity $\omega$. The right-hand side of (2) contains two forcing terms for the vertical motion with clearly different physical meanings: the first term is the vertical derivative of the absolute vorticity advection (F1), and the second term is the horizontal Laplacian of the thermal advection (F2).

As a second-order partial differential equation, (2) can be solved numerically once the boundary conditions are specified. To do this, on the left-hand side of (2), the second-order partial derivatives were replaced by the second-order finite difference approximations to derive the discretized equation. The forcing terms on the righthand side of (2) and $\sigma$ were calculated directly from the reanalysis datasets or model output. The zero boundary condition was applied at the horizontal boundaries of the global domain and at the top and bottom pressure levels. Starting with an initial $\omega$ field of zero everywhere, an iterative process was followed until successive iterations provided solutions that differed by a negligible amount.

This procedure to solve (2) was first applied to 20CR (Fig. 8). Similar results were derived from the NCEPNCAR reanalysis (not shown). The calculated pattern of $\omega$ differences between the AMO positive and 

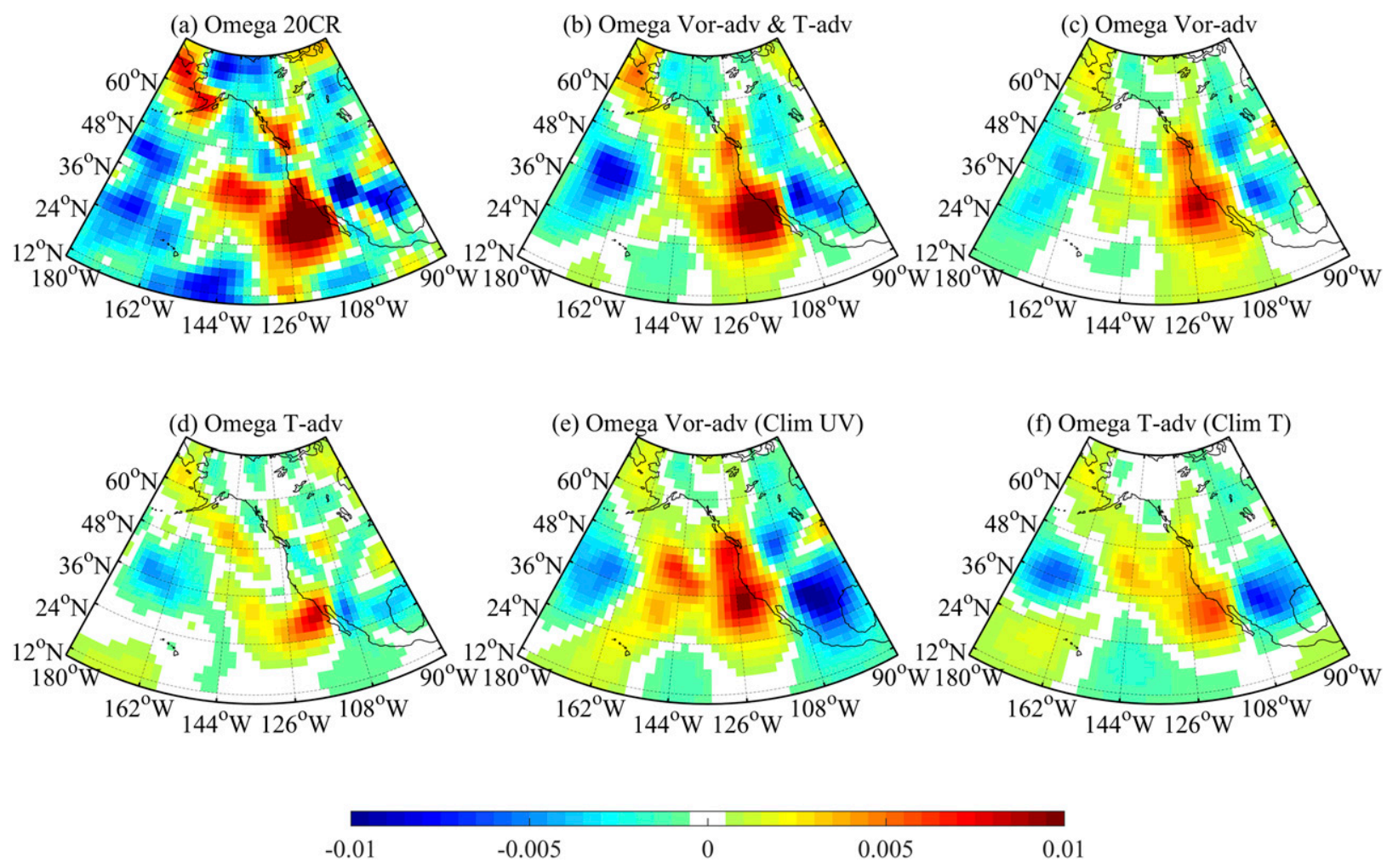

FIG. 8. The AMO-related 450-hPa vertical velocity anomalies ( $\mathrm{Pa} \mathrm{s}^{-1}$; positive downward) (a) from the 20CR direct output and (b) recalculated from (2). (c),(d) As in (b), but using the vorticity advection term and the thermal advection term, respectively. (e) As in (c), but using the climatological wind to calculate the vorticity advection term. (f) As in (d), but using the climatological air temperature to calculate the thermal advection term.

negative periods shows the observed region of enhanced subsidence over the northeastern Pacific and the center of maximums off the southwestern coast of North America as well as the surrounding upward motions (Figs. 8a,b). Both forcing terms make positive contributions to the downward motions. While the term F1 alone reproduces the general area of downward motions over the northeastern Pacific (Fig. 8c), F2 contributes more to the center of action at the southern tip of the southwestern coast of North America (Fig. 8d).

Changes in $\mathrm{F} 1$ and $\mathrm{F} 2$ during the different phases of the AMO could be due to changes of the circulation $\left(\mathbf{V}_{g}\right)$ and the modification of the vorticity $\left(\xi_{g}\right)$ or temperature $(T)$ patterns. To determine which is more important, we replaced each of these variables, one by one, with climatological values, recalculated the forcing terms, and then solved (2) to derive the corresponding $\omega$ differences. When $\mathbf{V}_{g}$ is set to its climatology, the F1 generates very similar and even stronger $\omega$ differences between the positive and negative periods of the AMO (Fig. 8e). In contrast, the F1 calculated using the climatological $\xi_{g}$ produces $\omega$ responses of the opposite sign (not shown). Thus, it is specifically the anomalous vorticity distribution that is responsible for the changes in the vorticity advection and thus F1. For F2, the $\omega$ responses remain similar when $T$ is set to its climatology (Fig. 8f) but become much weaker when $\mathbf{V}_{g}$ is set to its climatology (not shown), implying the importance of the anomalous wind in altering the thermal advection and thus the F2.

We also examined the underlying physical processes to understand how the AMO changes these two forcing terms. With the approximation that the Laplacian operator acts as a negative coefficient, according to (2) downward motion tends to occur where positive (negative) vorticity advection decreases (increases) with height or in regions of cold advection. The anomalous negative vorticity advection, which increases with height and reaches a maximum at $200 \mathrm{hPa}$, can be found over the northeastern Pacific during the positive phase of the AMO (Fig. 9a). Corresponding to the stationary wave pattern shown in Fig. 7a, there are alternating centers of positive and negative vorticity that establish the anomalous horizontal vorticity gradients. The negative vorticity advection usually occurs when the climatological winds (mainly westerly) blow from an anticyclone 
Vor-adv (color) \& Vor (contours) \& Clim UV
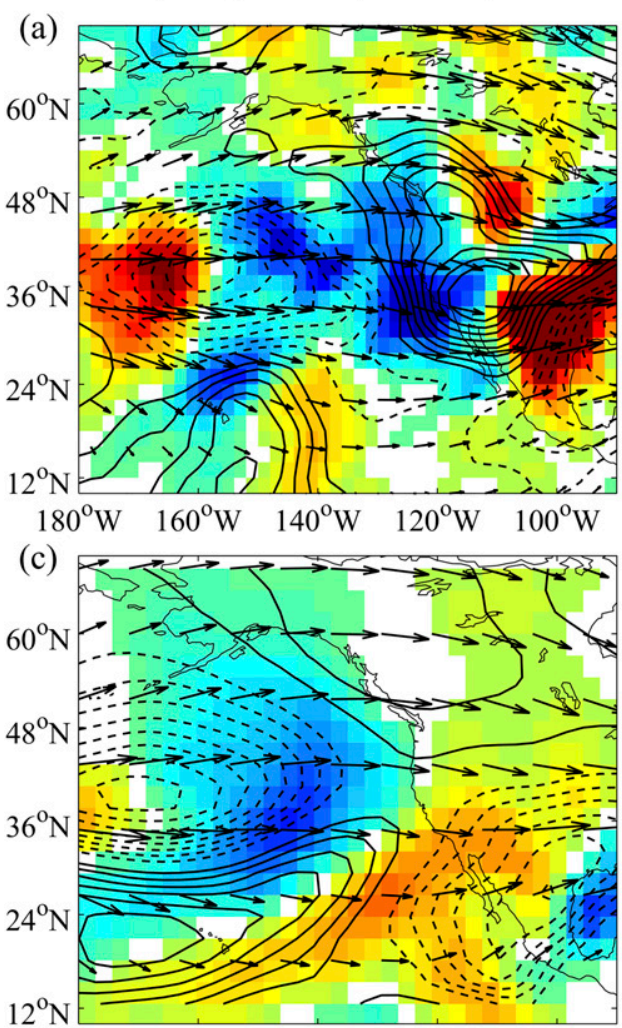

$180^{\circ} \mathrm{W} \quad 160^{\circ} \mathrm{W} \quad 140^{\circ} \mathrm{W} \quad 120^{\circ} \mathrm{W} \quad 100^{\circ} \mathrm{W}$

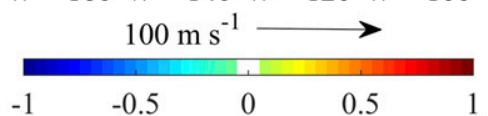

T-adv (color) \& Clim T (contours) \& UV

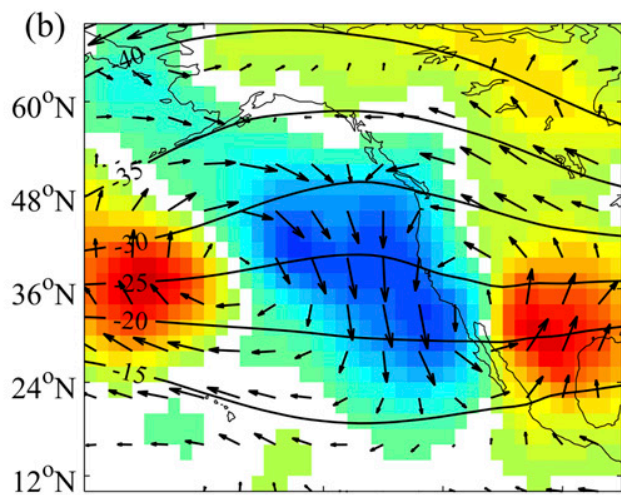

20CR $180^{\circ} \mathrm{W} \quad 160^{\circ} \mathrm{W} \quad 140^{\circ} \mathrm{W} \quad 120^{\circ} \mathrm{W} \quad 100^{\circ} \mathrm{W}$

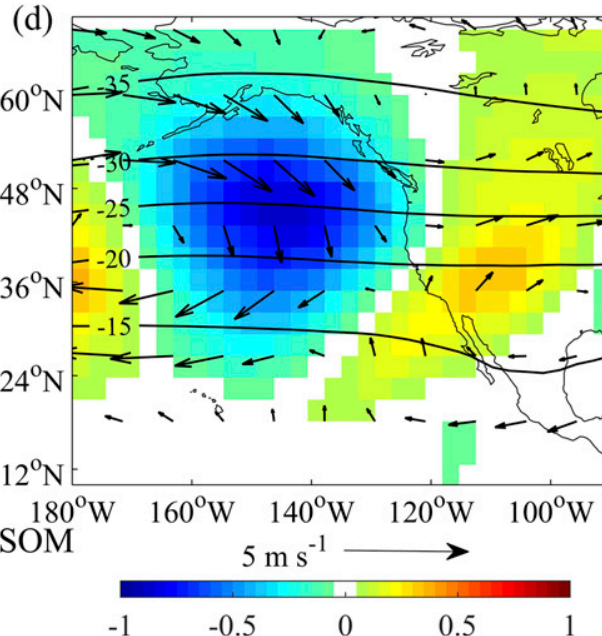

FIG. 9. (a) The AMO-related 200-hPa vorticity anomalies (contours with an interval of $0.5 \times 10^{-6} \mathrm{~s}^{-1}$; negative contours are dashed), vorticity advection anomalies $\left(10^{-10} \mathrm{~s}^{-2}\right.$; shading), and the wind climatology ( $\mathrm{m} \mathrm{s}^{-1}$; vectors) from 20CR. (b) The AMO-related 450-hPa wind anomalies ( $\mathrm{m} \mathrm{s}^{-1}$; vectors), thermal advection anomalies $\left(10^{-5 \circ} \mathrm{C} \mathrm{s}^{-1}\right.$; shading), and the air temperature climatology (contours; $\left.{ }^{\circ} \mathrm{C}\right)$ from $20 \mathrm{CR}$. (c),(d) As in (a),(b), but for the results from the AGCM-SOM experiment.

(which is characterized by negative vorticity) to a cyclone (characterized by positive vorticity). Such a configuration is found off the western coast of North America. The northeastern Pacific is also characterized by cold advection during the positive phase of the AMO (Fig. 9b). With colder air temperatures at higher latitudes, there exists a north-south temperature gradient in the climatological temperature distribution. The anomalous southward wind over the northeastern $\mathrm{Pa}$ cific results in anomalous cold advection that stretches southeastward along the western coast of North America. On both sides of this region of anomalous cold advection, warm advection also occurs because of anomalous northward winds and contributes to the upward motions. The anomalous winds could be related to the anticyclone over the NP and the cyclone over North America, which are part of the anomalous stationary wave pattern (Fig. 7a).
The $\omega$ equation in (2) also serves quite well to explain the model-produced downward motions over the northeastern Pacific (Figs. 10a,b). Both model experiments show very similar results. The $\omega$ responses from the vorticity advection forcing ( $\mathrm{F} 1$ term) are stronger and located farther south than those from the thermal advection forcing (F2 term) (Figs. 10c,d). The F1 term forces a stronger $\omega$ response when $\mathbf{V}_{g}$ is set to its climatological value (Fig. 10e). The $\omega$ responses are almost identical when F2 is calculated using the climatological $T$ (Fig. 10f). Therefore, as in the reanalysis datasets, the anomalous vorticity and winds in the model experiments are the essential factors to induce changes in the vorticity advection and the thermal advection, respectively. The model experiments also produce the negative vorticity advection (Fig. 9c) and cold advection (Fig. 9d) over the northeastern Pacific that facilitate the generation of the downward motions. It is clear that the 

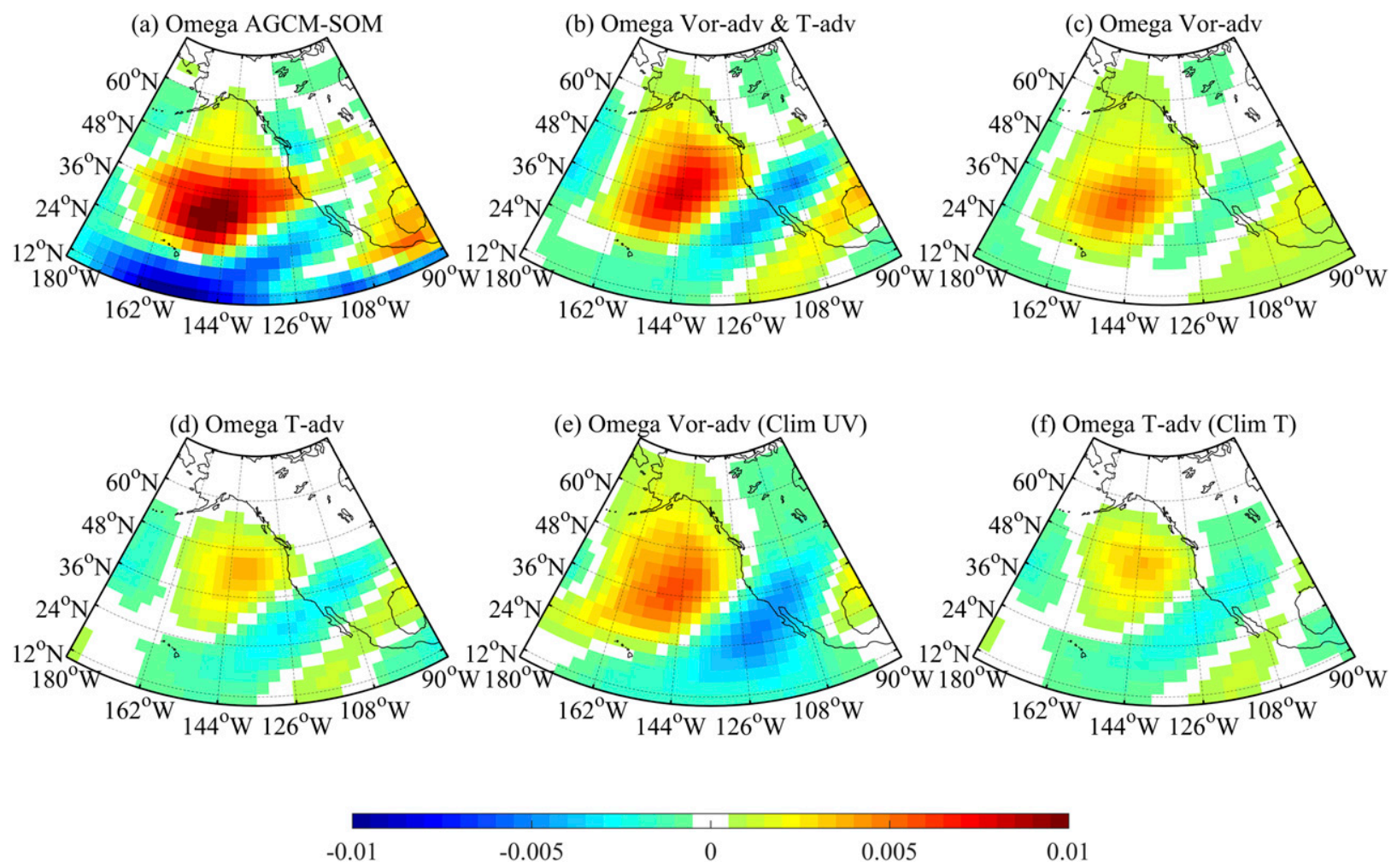

FIG. 10. As in Fig. 8, but for the AMO-related 450-hPa vertical velocity anomalies ( $\mathrm{Pa} \mathrm{s}^{-1}$; positive downward) (a) from the AGCM-SOM experiment direct output and (b)-(f) recalculated from (2) using different forcing terms.

anomalous vorticity and wind distributions are closely related to the cyclones and anticyclones in the modelproduced stationary wave. Note that the stationary wave patterns exhibit distinct differences in the reanalysis datasets and the model experiments (Fig. 7). In 20CR, the stationary wave at $200 \mathrm{hPa}$ over the NP is reflected eastward to form a cyclone over North America between $25^{\circ}$ and $55^{\circ} \mathrm{N}$, resulting in large zonal vorticity gradients and thus negative vorticity advection off the west coast of North America (Fig. 9a). In contrast, in the model experiments, the stationary wave over the NP is reflected toward North America at much higher latitudes $\left(\sim 60^{\circ} \mathrm{N}\right)$, and the simulated negative vorticity advection occurs farther northwestward. The model experiments also underestimate the southeastward extension of the anomalous southward winds and cold advection over the northeastern Pacific (Figs. 9b,d). Therefore, the lessrealistic simulation of the stationary wave response to the AMO is the primary reason why the model-simulated downward motions are biased northwestward.

Based on the diagnostic results from the reanalysis datasets and model experiments, we can conclude that it is the positive AMO-induced large-scale anomalous stationary wave that sets up the dynamic conditions that result in the enhanced subsidence over the northeastern
Pacific. The differences in the pattern of stationary wave can explain the different locations of the subsidence region in the reanalysis datasets and model experiments. It should be noted that this region of enhanced subsidence is centered on the southeastern flank of the NP barotropic anticyclone and extends farther southeastward (Fig. 11). Therefore, this subsidence process is essential in spreading the positive SLP anomalies over the NP farther southeastward into the subtropical high region and thus intensifying the subtropical high.

\section{Summary and discussion}

In this study we identified a series of mechanisms to explain how the AMO influences the mean strength of the NP subtropical high during boreal winter by analyzing both reanalysis datasets and output from model experiments. Our main findings can be summarized as follows (see Fig. 11 for a schematic summary): 1) in response to the tropical Atlantic warming during the positive phase of the AMO, ascending motions develop locally over the tropical Atlantic, while descending motions develop over the central tropical Pacific through a westward displacement of the Pacific Walker circulation; 2) the descending motions suppress deep 

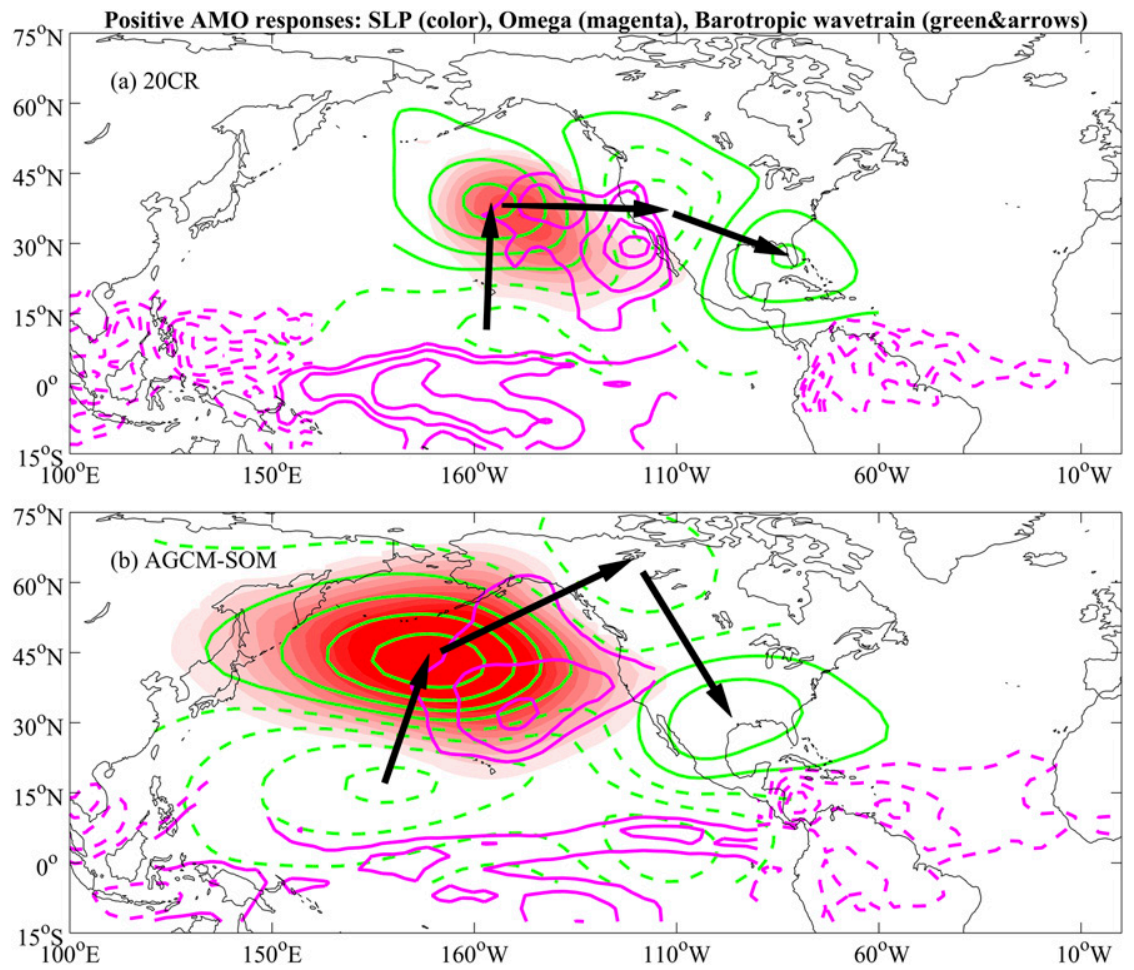

FIG. 11. A schematic diagram illustrating the relevant processes linking the positive phase of the AMO to North Pacific SLP increases (shading) based on results from (a) 20CR and (b) the AGCM-SOM experiment. The magenta contours show the $450-\mathrm{hPa}$ vertical velocity anomalies (contour interval of $0.005 \mathrm{~Pa} \mathrm{~s}^{-1}$; positive downward), and the green contours the barotropic streamfunction anomalies (contour interval of $0.5 \times 10^{6} \mathrm{~m}^{2} \mathrm{~s}^{-1}$ ) in response to the positive phase of the AMO. Negative contours are dashed. The arrows indicate the general trajectory of the stationary wave activity propagation.

convection in the central tropical Pacific, which in turn excites a baroclinic response within the tropics and an equivalent barotropic Rossby wave train that extends into the extratropical North Pacific; 3) the anomalous winds and vorticity distributions associated with the large-scale stationary wave pattern set up favorable conditions for anomalous descent over the northeastern Pacific via anomalous negative vorticity advection and cold advection; and 4) both a barotropic anticyclone over the North Pacific and the descending motions over the northeastern Pacific contribute to increase the SLP, resulting in a strengthening and also a northwestward extension in the North Pacific subtropical high. We suggest that the enhanced subsidence over the northeastern Pacific should have more impact on the subtropical high, since it mainly occurs to the southeast of the barotropic anticyclone and lies closer to the subtropical high region (Fig. 11). Similar influences of the tropical Atlantic on the Pacific can also be found on the interannual time scale. For example, the northern tropical Atlantic spring warming tends to trigger the central tropical Pacific La Niña event in the following winter (Ham et al. 2013), which in turn forces wave train pattern into the extratropical North Pacific (Yu et al. 2012b) (shown in Fig. S7 of the supplementary material).

Although the above processes are all found in both the reanalysis datasets and our model experiments, there exist some differences in the details between the observed and simulated AMO responses (Fig. 11). For example, the anomalous barotropic anticyclone only appears on the eastern side of the NP and stretches south to $22^{\circ} \mathrm{N}$ in $20 \mathrm{CR}$ (Fig. 11a) but covers nearly the entire extratropical NP north of $30^{\circ} \mathrm{N}$ in the model experiments (Fig. 11b). The region of enhanced subsidence over the northeastern Pacific also tends to be located farther southeastward in $20 \mathrm{CR}$ than in the model experiments. These differences explain why the modelproduced positive SLP anomalies over the NP are located farther northward. These model deficiencies are ultimately linked to the less-realistic patterns of simulated stationary waves. The lack of wave activity propagation into the NA also causes the model to be less successful in simulating the NAO-like winter SLP responses to the AMO. 
Why do the model experiments produce stationary wave patterns that differ from those in the reanalysis datasets? Given that the extratropical atmospheric circulation and stationary wave responses are very sensitive to the tropical forcing patterns (e.g., DeWeaver and Nigam 2004; Yu et al. 2012b; Park and An 2014; Jo et al. 2015), it is our hypothesis that the lack of ascending anomalies and enhanced convection over the western tropical Pacific in the model experiments could be one factor leading to the different stationary wave patterns, which in turn determine the locations of the barotropic anticyclone and the enhanced subsidence (Fig. 11). A climate model experiment with the full ocean-atmosphere coupling in the Indo-Pacific region is likely to produce more realistic SST and atmospheric responses to the AMO forcing since the ocean dynamics and its interactions with the atmosphere could play a crucial role. Deficiencies in the simulation of the climatological midlatitude jet stream may also play a role. It would be of great interest to examine if the global climate models from phase 5 of the Coupled Model Intercomparison Project (CMIP5) are capable of reproducing the remote influence of the AMO on the Pacific, since many previous model evaluation studies have focused either on the Pacific itself (e.g., Lyu et al. 2016) or on the Atlantic (e.g., Peings et al. 2016). A multimodel comparison would also help to identify the key processes responsible for the model deficiencies.

This study highlights the key role of tropical Atlantic SST anomalies in forcing the Pacific responses through the tropical Pacific pathway. It should be noted that the AMO-related extratropical NA SST anomalies are of similar magnitude to those in the tropical Atlantic (Fig. 2). Previous modeling studies have shown that the tropical NA AMO SST forcing alone can produce the majority of the NP SLP responses to the AMO, while the extratropical NA SST forcing alone produces very weak or even opposite impacts on the NP SLP (Sutton and Hodson 2007; Okumura et al. 2009; Davini et al. 2015). However, it is possible that the extratropical NA SST forcing can amplify the NP responses to tropical NA SST forcing through the midlatitude pathway (Zhang and Delworth 2007; Wu et al. 2008; Agarwal et al. 2014; Zhang and Zhao 2015). For example, the extratropical NA warm SST anomalies could weaken transient eddy activity over the midlatitude NP, leading to a poleward shift of the midlatitude jet stream and thus an increase in SLP over the NP (Zhang and Delworth 2007). The relative roles of the tropical and midlatitude processes in generating the AMO responses require further investigation.
Acknowledgments. We thank three anonymous reviewers for their helpful comments. This research was supported by the National Science Foundation Grants AGS-1233542 and AGS-1505145. The 20CR, NCEPNCAR reanalysis, ERSST datasets, and the AMO index were obtained from the NOAA/ERSL/PSD (http:// www.esrl.noaa.gov/psd/). The ERA-20C data are available at the ECMWF (http://www.ecmwf.int/en/research/ climate-reanalysis/era-20c). We would like to acknowledge high-performance computing support from Yellowstone provided by NCAR's Computational and Information Systems Laboratory, sponsored by the National Science Foundation.

\section{REFERENCES}

Agarwal, N., A. Köhl, C. R. Mechoso, and D. Stammer, 2014: On the early response of the climate system to a meltwater input from Greenland. J. Climate, 27, 8276-8296, doi:10.1175/ JCLI-D-13-00762.1.

Ashok, K., S. K. Behera, S. A. Rao, H. Weng, and T. Yamagata, 2007: El Niño Modoki and its possible teleconnection. J. Geophys. Res., 112, C11007, doi:10.1029/2006JC003798.

Clement, A., K. Bellomo, L. N. Murphy, M. A. Cane, T. Mauritsen, G. Rädel, and B. Stevens, 2015: The Atlantic multidecadal oscillation without a role for ocean circulation. Science, $\mathbf{3 5 0}$, 320-324, doi:10.1126/science.aab3980.

Collins, W. D., and Coauthors, 2006: The formulation and atmospheric simulation of the Community Atmosphere Model version 3 (CAM3). J. Climate, 19, 2144-2161, doi:10.1175/ JCLI3760.1.

Compo, G. P., and Coauthors, 2011: The Twentieth Century Reanalysis project. Quart. J. Roy. Meteor. Soc., 137, 1-28, doi:10.1002/qj.776.

Davini, P., J. von Hardenberg, and S. Corti, 2015: Tropical origin for the impacts of the Atlantic Multidecadal Variability on the Euro-Atlantic climate. Environ. Res. Lett., 10, 094010, doi:10.1088/1748-9326/10/9/094010.

Delworth, T., S. Manabe, and R. J. Stouffer, 1993: Interdecadal variations of the thermohaline circulation in a coupled oceanatmosphere model. J. Climate, 6, 1993-2011, doi:10.1175/ 1520-0442(1993)006<1993:IVOTTC>2.0.CO;2.

DeWeaver, E., and S. Nigam, 2004: On the forcing of ENSO teleconnections by anomalous heating and cooling. $J$. Climate, 17, 3225-3235, doi:10.1175/1520-0442(2004)017<3225: OTFOET $>2.0 . \mathrm{CO} ; 2$.

Ding, Q., J. M. Wallace, D. S. Battisti, E. J. Steig, A. J. E. Gallant, H.-J. Kim, and L. Geng, 2014: Tropical forcing of the recent rapid Arctic warming in northeastern Canada and Greenland. Nature, 509, 209-212, doi:10.1038/nature13260.

Dong, B., and R. T. Sutton, 2007: Enhancement of ENSO variability by a weakened Atlantic thermohaline circulation in a coupled GCM. J. Climate, 20, 4920-4939, doi:10.1175/ JCLI4284.1.

,,-- and A. A. Scaife, 2006: Multidecadal modulation of El Niño-Southern Oscillation (ENSO) variance by Atlantic Ocean sea surface temperatures. Geophys. Res. Lett., 33, L08705, doi:10.1029/2006GL025766.

Enfield, D. B., A. M. Mestas-Nuñez, and P. J. Trimble, 2001: The Atlantic multidecadal oscillation and its relation to rainfall 
and river flows in the continental U.S. Geophys. Res. Lett., 28 , 2077-2080, doi:10.1029/2000GL012745.

England, M. H., and Coauthors, 2014: Recent intensification of wind-driven circulation in the Pacific and the ongoing warming hiatus. Nat. Climate Change, 4, 222-227, doi:10.1038/ nclimate2106.

Gill, A. E., 1980: Some simple solutions for heat-induced tropical circulation. Quart. J. Roy. Meteor. Soc., 106, 447-462, doi:10.1002/qj.49710644905.

Goswami, B. N., M. S. Madhusoodanan, C. P. Neema, and D. Sengupta, 2006: A physical mechanism for North Atlantic SST influence on the Indian summer monsoon. Geophys. Res. Lett., 33, L02706, doi:10.1029/2005GL024803.

Ham, Y.-G., J.-S. Kug, J.-Y. Park, and F.-F. Jin, 2013: Sea surface temperature in the north tropical Atlantic as a trigger for El Niño/Southern Oscillation events. Nat. Geosci., 6, 112-116, doi:10.1038/ngeo1686.

Heckley, W. A., and A. E. Gill, 1984: Some simple analytic solutions to the problems of forced equatorial long waves. Quart. J. Roy. Meteor. Soc., 110, 203-217, doi:10.1002/ qj. 49711046314

Hodson, D. L. R., R. T. Sutton, C. Cassou, N. Keenlyside, Y. Okumura, and T. Zhou, 2010: Climate impacts of recent multidecadal changes in Atlantic Ocean sea surface temperature: A multimodel comparison. Climate Dyn., 34, 10411058, doi:10.1007/s00382-009-0571-2.

Horel, J. D., and J. M. Wallace, 1981: Planetary-scale atmospheric phenomena associated with the Southern Oscillation. Mon Wea. Rev., 109, 813-829, doi:10.1175/1520-0493(1981)109<0813: PSAPAW $>2.0 . \mathrm{CO} ; 2$.

Hoskins, B. J., and D. J. Karoly, 1981: The steady linear response of a spherical atmosphere to thermal and orographic forcing. J. Atmos. Sci., 38, 1179-1196, doi:10.1175/ 1520-0469(1981)038<1179:TSLROA $>2.0$. CO;2.

Ji, X., J. D. Neelin, S.-K. Lee, and C. R. Mechoso, 2014: Interhemispheric teleconnections from tropical heat sources in intermediate and simple models. J. Climate, 27, 684-697, doi:10.1175/JCLI-D-13-00017.1.

Jo, H.-S., S.-W. Yeh, and S.-K. Lee, 2015: Changes in the relationship in the SST variability between the tropical Pacific and the North Pacific across the 1998/1999 regime shift. Geophys. Res. Lett., 42, 7171-7178, doi:10.1002/2015GL065049.

Kalnay, E., and Coauthors, 1996: The NCEP/NCAR 40-Year Reanalysis Project. Bull. Amer. Meteor. Soc., 77, 437-471, doi:10.1175/1520-0477(1996)077<0437:TNYRP>2.0.CO;2.

Kang, I.-S., H.-h. No, and F. Kucharski, 2014: ENSO amplitude modulation associated with the mean SST changes in the tropical central Pacific induced by Atlantic multidecadal oscillation. J. Climate, 27, 7911-7920, doi:10.1175/JCLI-D-14-00018.1.

Kao, H.-Y., and J.-Y. Yu, 2009: Contrasting eastern-Pacific and central-Pacific types of ENSO. J. Climate, 22, 615-632, doi:10.1175/2008JCLI2309.1.

Knight, J. R., C. K. Folland, and A. A. Scaife, 2006: Climate impacts of the Atlantic multidecadal oscillation. Geophys. Res. Lett., 33, L17706, doi:10.1029/2006GL026242.

Kucharski, F., and Coauthors, 2016: Atlantic forcing of Pacific decadal variability. Climate Dyn., 46, 2337-2351, doi:10.1007/ s00382-015-2705-z.

Kug, J.-S., F.-F. Jin, and S.-I. An, 2009: Two types of El Niño events: Cold tongue El Niño and warm pool El Niño. J. Climate, 22, 1499-1515, doi:10.1175/2008JCLI2624.1.

Larkin, N. K., and D. E. Harrison, 2005: Global seasonal temperature and precipitation anomalies during El Niño autumn and winter. Geophys. Res. Lett., 32, L16705, doi:10.1029/ 2005GL022860.

Lee, S.-K., C. Wang, and B. E. Mapes, 2009: A simple atmospheric model of the local and teleconnection responses to tropical heating anomalies. J. Climate, 22, 272-284, doi:10.1175/ 2008JCLI2303.1.

- C. R. Mechoso, C. Wang, and J. D. Neelin, 2013: Interhemispheric influence of the northern summer monsoons on southern subtropical anticyclones. J. Climate, 26, 10193 10 204, doi:10.1175/JCLI-D-13-00106.1.

Lee, T., and M. J. McPhaden, 2010: Increasing intensity of El Niño in the central-equatorial Pacific. Geophys. Res. Lett., 37, L14603, doi:10.1029/2010GL044007.

Li, X., D. M. Holland, E. P. Gerber, and C. Yoo, 2014: Impacts of the north and tropical Atlantic Ocean on the Antarctic Peninsula and sea ice. Nature, 505, 538-542, doi:10.1038/ nature12945.

, S.-P. Xie, S. T. Gille, and C. Yoo, 2015: Atlantic-induced pantropical climate change over the past three decades. Nat. Climate Change, 6, 275-279, doi:10.1038/nclimate2840.

Lyu, K., X. Zhang, J. A. Church, and J. Hu, 2016: Evaluation of the interdecadal variability of sea surface temperature and sea level in the Pacific in CMIP3 and CMIP5 models. Int. J. Climatol., 36, 3723-3740, doi:10.1002/joc.4587.

Ma, S., and T. Zhou, 2016: Robust strengthening and westward shift of the tropical Pacific Walker circulation during 1979-2012: A comparison of 7 sets of reanalysis data and 26 CMIP5 models. J. Climate, 29, 3097-3118, doi:10.1175/ JCLI-D-15-0398.1.

McGregor, S., A. Timmermann, M. F. Stuecker, M. H. England, M. Merrifield, F.-F. Jin, and Y. Chikamoto, 2014: Recent Walker circulation strengthening and Pacific cooling amplified by Atlantic warming. Nat. Climate Change, 4, 888-892, doi:10.1038/nclimate2330.

Okumura, Y. M., C. Deser, A. Hu, A. Timmermann, and S.-P. Xie, 2009: North Pacific climate response to freshwater forcing in the subarctic North Atlantic: Oceanic and atmospheric pathways. J. Climate, 22, 1424-1445, doi:10.1175/2008JCLI2511.1.

Park, J.-H., and S.-I. An, 2014: The impact of tropical western Pacific convection on the North Pacific atmospheric circulation during the boreal winter. Climate Dyn., 43, 2227-2238, doi:10.1007/s00382-013-2047-7.

Peings, Y., and G. Magnusdottir, 2014: Forcing of the wintertime atmospheric circulation by the multidecadal fluctuations of the North Atlantic Ocean. Environ. Res. Lett., 9, 034018, doi:10.1088/1748-9326/9/3/034018.

_, and - 2015: Wintertime atmospheric response to Atlantic multidecadal variability: Effect of stratospheric representation and ocean-atmosphere coupling. Climate Dyn., 47, 10291047, doi:10.1007/s00382-015-2887-4.

, G. Simpkins, and G. Magnusdottir, 2016: Multidecadal fluctuations of the North Atlantic Ocean and feedback on the winter climate in CMIP5 control simulations. J. Geophys. Res., 121, 2571-2592, doi:10.1002/2015JD024107.

Plumb, R. A., 1985: On the three-dimensional propagation of stationary waves. J. Atmos. Sci., 42, 217-229, doi:10.1175/ 1520-0469(1985)042<0217:OTTDPO > 2.0.CO;2.

Räisänen, J., 1995: Factors affecting synoptic-scale vertical motions: A statistical study using a generalized omega equation. Mon. Wea. Rev., 123, 2447-2460, doi:10.1175/1520-0493(1995)123<2447: FASSVM $>2.0 . \mathrm{CO} ; 2$.

Simpkins, G. R., S. McGregor, A. S. Taschetto, L. M. Ciasto, and M. H. England, 2014: Tropical connections to climatic change 
in the extratropical Southern Hemisphere: The role of Atlantic SST trends. J. Climate, 27, 4923-4936, doi:10.1175/ JCLI-D-13-00615.1.

- Y Y. Peings, and G. Magnusdottir, 2016: Pacific influences on tropical Atlantic teleconnections to the Southern Hemisphere high latitudes. J. Climate, 29, 6425-6444, doi:10.1175/ JCLI-D-15-0645.1.

Smith, T. M., R. W. Reynolds, T. C. Peterson, and J. Lawrimore, 2008: Improvements to NOAA's historical merged landocean surface temperature analysis (1880-2006). J. Climate, 21, 2283-2296, doi:10.1175/2007JCLI2100.1.

Stickler, A., and Coauthors, 2014: ERA-CLIM: Historical surface and upper-air data for future reanalyses. Bull. Amer. Meteor. Soc., 95, 1419-1430, doi:10.1175/BAMS-D-13-00147.1.

Sun, C., J. Li, and S. Zhao, 2015: Remote influence of Atlantic multidecadal variability on Siberian warm season precipitation. Sci. Rep., 5, 16853 , doi:10.1038/srep16853.

Sung, M.-K., S.-I. An, B.-M. Kim, and J.-S. Kug, 2015: Asymmetric impact of Atlantic multidecadal oscillation on El Niño and La Niña characteristics. Geophys. Res. Lett., 42, 4998-5004, doi:10.1002/2015GL064381.

Sutton, R. T., and D. L. R. Hodson, 2007: Climate response to basin-scale warming and cooling of the North Atlantic Ocean. J. Climate, 20, 891-907, doi:10.1175/JCLI4038.1.

Svendsen, L., N. G. Kvamst $\varnothing$, and N. Keenlyside, 2014: Weakening AMOC connects equatorial Atlantic and Pacific interannual variability. Climate Dyn., 43, 2931-2941, doi:10.1007/ s00382-013-1904-8.

Timmermann, A., S.-I. An, U. Krebs, and H. Goosse, 2005: ENSO suppression due to weakening of the North Atlantic thermohaline circulation. J. Climate, 18, 3122-3139, doi:10.1175/ JCLI3495.1.

- and Coauthors, 2007: The influence of a weakening of the Atlantic meridional overturning circulation on ENSO. J. Climate, 20, 4899-4919, doi:10.1175/JCLI4283.1.

Wang, C., S.-K. Lee, and C. R. Mechoso, 2010: Interhemispheric influence of the Atlantic warm pool on the southeastern Pacific. J. Climate, 23, 404-418, doi:10.1175/2009JCLI3127.1.

Webster, P. J., 1981: Mechanisms determining the atmospheric response to sea surface temperature anomalies. J. Atmos. Sci., 38, 554-571, doi:10.1175/1520-0469(1981)038<0554: MDTART $>2.0 . \mathrm{CO} ; 2$

Wu, L., C. Li, C. Yang, and S.-P. Xie, 2008: Global teleconnections in response to a shutdown of the Atlantic meridional overturning circulation. J. Climate, 21, 3002-3019, doi:10.1175/ 2007JCLI1858.1.
Yeh, S.-W., X. Wang, C. Wang, and B. Dewitte, 2015: On the relationship between the North Pacific climate variability and the central Pacific El Niño. J. Climate, 28, 663-677, doi:10.1175/JCLI-D-14-00137.1.

Yu, B., and G. J. Boer, 2002: The roles of radiation and dynamical processes in the El Niño-like response to global warming. Climate Dyn., 19, 539-553, doi:10.1007/s00382-002-0244-x.

Yu, J.-Y., and H.-Y. Kao, 2007: Decadal changes of ENSO persistence barrier in SST and ocean heat content indices: 1958-2001. J. Geophys. Res., 112, D13106, doi:10.1029/ 2006JD007715.

_ _ and S. T. Kim, 2011: Relationships between extratropical sea level pressure variations and the central Pacific and eastern Pacific types of ENSO. J. Climate, 24, 708-720, doi:10.1175/ 2010JCLI3688.1.

—- H.-Y. Kao, and T. Lee, 2010: Subtropics-related interannual sea surface temperature variability in the central equatorial Pacific. J. Climate, 23, 2869-2884, doi:10.1175/ 2010JCLI3171.1.

—, M.-M. Lu, and S. T. Kim, 2012a: A change in the relationship between tropical central Pacific SST variability and the extratropical atmosphere around 1990. Environ. Res. Lett., 7, 034025, doi:10.1088/1748-9326/7/3/034025.

— Y. Zou, S. T. Kim, and T. Lee, 2012b: The changing impact of El Niño on US winter temperatures. Geophys. Res. Lett., 39, L15702, doi:10.1029/2012GL052483.

_ P.-k. Kao, H. Paek, H.-H. Hsu, C.-W. Hung, M.-M. Lu, and S.-I. An, 2015a: Linking emergence of the central Pacific El Niño to the Atlantic multidecadal oscillation. J. Climate, $\mathbf{2 8}$, 651-662, doi:10.1175/JCLI-D-14-00347.1.

— H. Haek, E. S. Saltzman, and T. Lee, 2015b: The early 1990s change in ENSO-PSA-SAM relationships and its impact on Southern Hemisphere climate. J. Climate, 28, 9393-9408, doi:10.1175/JCLI-D-15-0335.1.

Zhang, L., and C. Zhao, 2015: Processes and mechanisms for the model SST biases in the North Atlantic and North Pacific: A link with the Atlantic meridional overturning circulation. J. Adv. Model. Earth Syst., 7, 739-758, doi:10.1002/ 2014MS000415.

Zhang, R., and T. L. Delworth, 2005: Simulated tropical response to a substantial weakening of the Atlantic thermohaline circulation. J. Climate, 18, 1853-1860, doi:10.1175/ JCLI3460.1.

— and - 2007: Impact of the Atlantic multidecadal oscillation on North Pacific climate variability. Geophys. Res. Lett., 34, L23708, doi:10.1029/2007GL031601. 